\title{
Comparison of Cucumber Mosaic Virus Isolates by Double-Stranded RNA Analysis*
}

\author{
Wei Qin Wang**, Tomohide Natsuaki**, Seiichi OKuda** \\ and Michiaki TeranaKA**
}

Key words: cucumber mosaic virus isolates, double-stranded RNA, electrophoresis.

Cucumber mosaic virus (CMV), the type member of the cucumovirus group, contains four positive sense single-stranded(ss) RNA species designated RNA1 4. CMV has a very broad host range and is one of the most widespread and economically important viruses. Numerous isolates (strains) of CMV have been reported on the basis of host range and symptoms ${ }^{1)}$, but it is difficult to classify and identify genuine differences among them. Replicative form doublestranded RNAs (RF-dsRNAs), that are twice the size of viral genomic ssRNA have been isolated from plants infected with RNA viruses ${ }^{2}$. Analytical results of the dsRNA species have been used for diagnosis as well as for virus classification ${ }^{3-6}$. This report deals with the comparison of the CMV isolates by dsRNA analysis, demonstrating the effectiveness of the method in such identification, and suggests that the individual isolates may be distinguished by this means.

Six CMV isolates were isolated from naturally infected plants collected in Tochigi, Ibaraki, and Shizuoka prefectures and designated PU, TU, KU, IU, EU and SU, respectively, for this study (Table 1). All isolates were propagated in Nicotiana tabacum cv. Xanthi.

DsRNAs were extracted from plants infected by the six isolates as described by Dodds and Bar-Joseph $\left.(1983)^{3}\right)$. Frozen leaf tissue $(5 \mathrm{~g})$ which had been stored at $-80 \mathrm{C}$ was ground with a mortar and pestle to a fine powder and homogenized with $10 \mathrm{ml}$ of $2 \times$ STE buffer $(1 \times$ STE $=$ $0.1 \mathrm{M} \mathrm{NaCl}, 0.05 \mathrm{M}$ Tris-HCl, $1 \mathrm{mM}$ EDTA, $\mathrm{pH} 7.0$ ) containing $1 \% \mathrm{SDS}, 0.1 \mathrm{ml}$ of 2-mercaptoethanol, $10 \mathrm{ml}$ of $80 \%$ phenol containing $0.1 \% 8$-hydroxyquinoline, $10 \mathrm{ml}$ of chloroform and $0.4 \mathrm{ml}$ of pentanol. After the mixture was centrifuged at $8,000 \times g$ for $10 \mathrm{~min}$, ethanol was added to a final concentration of $15 \%$. Following a second centrifugation, $1.2 \mathrm{~g}$ of CF-11 cellulose powder (Whatman) was added to the supernatant and the mixture was stirred for $15 \mathrm{~min}$ at $4 \mathrm{C}$. The powder was placed in a glass column and washed with $100 \mathrm{ml}$ of $15 \%$ ethanol $/ 85 \%$ STE buffer. The dsRNA was eluted with $20 \mathrm{ml}$ of ethanol-free STE buffer. The eluate was then mixed with $1 \mathrm{~g}$ of CF-11 cellulose powder and $3.5 \mathrm{ml}$ of ethanol and subjected to a second cycle of chromatography. The second column was washed with $100 \mathrm{ml}$ of $15 \%$ ethanol $/ 85 \%$ STE. Finally the dsRNA was eluted with $16 \mathrm{ml}$ of STE buffer, made to $30 \mathrm{mM} \mathrm{MgCl}$, incubated for $20 \mathrm{~min}$ at $30 \mathrm{C}$ with $20 \mu \mathrm{g}$ of DNase I and concentrated by ethanol precipitation. The dsRNA

\footnotetext{
* Supported in part by a Grant-in-Aid for Scientific Research (No. 59440011 and No. 62560036) from the Ministry of Education, Science and Culture of Japan

** Faculty of Agriculture, Utsunomiya University, Mine-machi, Utsunomiya 321, Japan 宇都宮大学 農学部

1) Kaper, J.M. and Waterworth, H.E. (1981). In Handbook of Plant Virus Infections. Comparative Diagnosis (Kurstak, E. ed.). Elsevier/North-Holland Biomedical Press, Amsterdam. pp. 257-332. 2) Dodds, J.A., Morris, T.J. and Jordan, R.L. (1984). Ann. Rev. Phytopathol. 22: 151-168. 3) Dodds, J.A. and Bar-Joseph, M. (1983). Phytopathology 73: 419-423. 4) Gildow, F.E., Ballinger, M.E. and Rochow, W.F. (1983). Ibid. 73: 1570-1572. 5) Valverde, R.A., Dodds, J.A. and Heick, J.A. (1986). Ibid. 76: 459-465. 6) Dodds, J.A., Jarupat, T., Lee, J.G. and Roistacher, C.N. (1987). Ibid. 77: 442-447.
} 
pellet was dried under vacuum and then suspended in $80 \mu \mathrm{l}$ of sterilized distilled water containing $10 \%$ sucrose and $0.001 \%$ bromophenol blue.

The dsRNAs were analyzed by electrophoresis in $5 \%$ polyacrylamide slab gels $(135 \times 120 \times$ $1 \mathrm{~mm}$ ) prepared with an acrylamide-bisacrylamide ratio of $30: 1.5(\mathrm{w} / \mathrm{w})$ and Tris-Borate-EDTA (TBE) buffer. Each dsRNA sample of 1 to $5 \mu \mathrm{l}$ was electrophoresed. After electrophoresis at $10 \mathrm{~mA}$ for $10 \sim 12 \mathrm{hr}$, the dsRNA bands were visualized using a Daiichi silver staining kit (Daiichikagaku Co., Tokyo, Japan).

The CMV antiserum was produced against the cucumber isolate which was serologically identical to serotype $\mathrm{Y}^{7)}$ of CMV (unpublished data). When six CMV isolates were compared in agar gel diffusion test with the antiserum, a single continuous line produced by four isolates (TU, KU, IU, and SU) spurred over the line between EU and PU isolates (Fig. 1). Serological comparisons with CMV-Y and CMV-P showed that TU, KU, IU, and SU isolates were identified as serotype $Y^{7}$ ) and the others were serotype $P^{7)}$ (data not shown; Table 2).

The effect of host species or cultivars on electrophoretic patterns of dsRNAs was examined. No variation was observed among profiles of dsRNAs isolated from CMV-KU infected plants of $N$. tabacum cv. Xanthi, cv. Xanthi nc, $N$. glutinosa, Lycopersicon esculentum cv. Fukuji and Cucumis sativus cv. Suyo (Fig. 2).

DsRNAs prepared from tobacco tissue infected with CMV isolates were co-electrophoresed. Differences in the electrophoretic mobility of dsRNA1 3 associated with each CMV isolate were observed (Figs. 3 and 4) and dsRNAs of CMV-IU and CMV-SU were found to be the same (Fig. 3K). No difference was detected in dsRNA4 mobility among all isolates. In the case of dsRNA3, the mobility was indistinct among isolates belonging to the serotype $\mathrm{Y}$ but it was apparently distinguishable from isolates of serotype P. The dsRNA3 of CMV-EU and CMV-

Table 1. Isolates of CMV used in this study

\begin{tabular}{clll}
\hline \hline Isolate & Host & \multicolumn{1}{c}{ Symptoms } & \multicolumn{1}{c}{ Location and date of isolation } \\
\hline PU & Tomato & stem and leaf necrosis & Kanuma, Tochigi Pref., Dec. 1982 \\
TU & Tomato & stem necrosis & Mooka, Tochigi Pref., July 1983 \\
KU & Squash & mosaic, fruit deformation & Oyama, Tochigi Pref., Aug. 1984 \\
IU & Tomato & mosaic, fanleaf & Ishioka, Ibaraki Pref., Oct. 1984 \\
EU & Eggplant & mild mosaic & Edosaki, Ibaraki Pref., July 1985 \\
SU & Tomato & mosaic, fanleaf & Kikugawa, Shizuoka Pref., Oct. 1985 \\
\hline
\end{tabular}

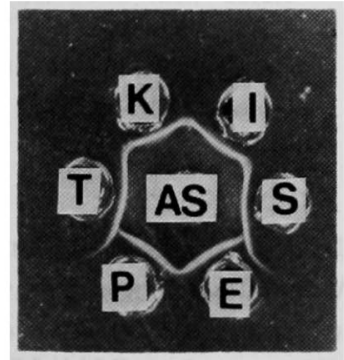

Fig. 1. Gel immunodiffusion test : central well (As) contained antiserum to $\mathrm{CMV}-\mathrm{Y}$, the rest contained CMV-TU (T), KU (K), IU (I), SU (S), EU (E) and PU (P).

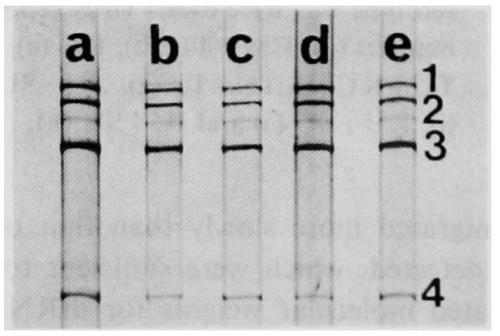

Fig. 2. Effect of host on electrophoretic pattern of dsRNAs from plants infected with CMVKU. Nicotiana tabacum cv. Xanthi (a), cv. Xanthi nc (b), N.glutinosa (c), Lycopersicon esculentum cv. Fukuju (d) and Cucumis sativus cv. Suyo (e).

7) Hanada, K. and Tochihara, H. (1980). Ann. Phytopath. Soc. Japan 46: 159-168. 
Table 2. Serotype of CMV isolates and molecular weight estimates of double-stranded RNAs associated with the isolates

\begin{tabular}{ccccc}
\hline \multirow{2}{*}{ Isolate } & Serotype & \multicolumn{3}{c}{ Molecular weight $\left(\times 10^{6}\right) *$} \\
\cline { 5 - 5 } & & dsRNA1 & dsRNA2 & dsRNA3 \\
\hline TU & Y & 2.40 & 2.25 & 1.56 \\
KU & Y & 2.55 & 2.25 & 1.56 \\
IU & Y & 2.40 & 2.27 & 1.56 \\
SU & Y & 2.40 & 2.27 & 1.56 \\
EU & P & 2.35 & 2.29 & 1.62 \\
PU & P & 2.35 & 2.31 & 1.62 \\
\hline
\end{tabular}

* Molecular weight estimates determined from the mobilities of CMV isolate dsRNAs relative to rice dwarf virus genomic dsRNA ${ }^{\text {s) }}$.

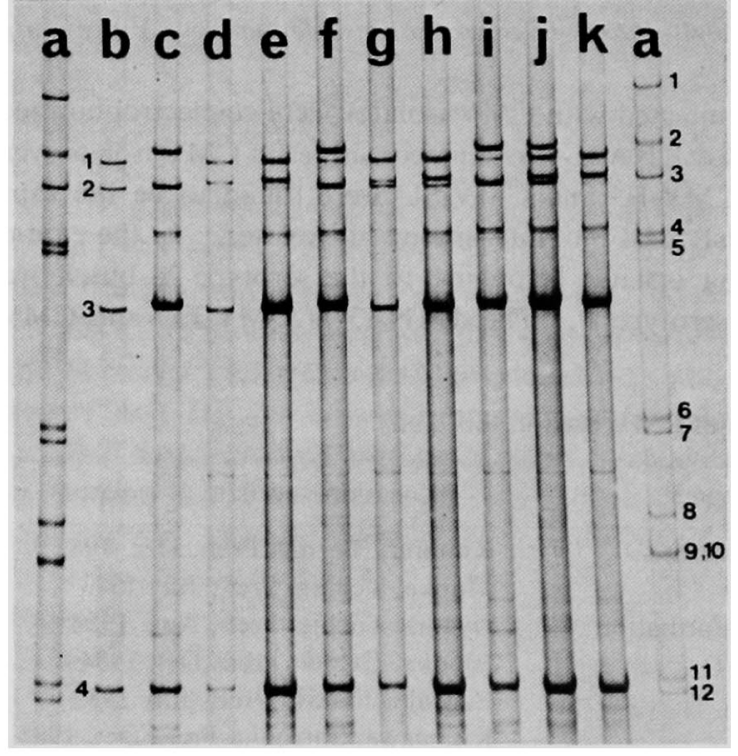

Fig. 3. Electrophoresis of dsRNAs from N. tabacum cv. Xanthi infected with $\mathrm{CMV}$ isolates belonging to serotype $\mathrm{Y}$. Rice dwarf virus genomic dsRNA as markers (a), CMV-TU (b), KU (c), IU (d), SU (e), $T U+K U(f), T U+I U(g), T U+S U(h), T U+K U$ (i), $\mathbf{K U}+\mathbf{S U}(\mathrm{j})$ and $\mathrm{IU}+\mathrm{SU}(\mathrm{k})$.

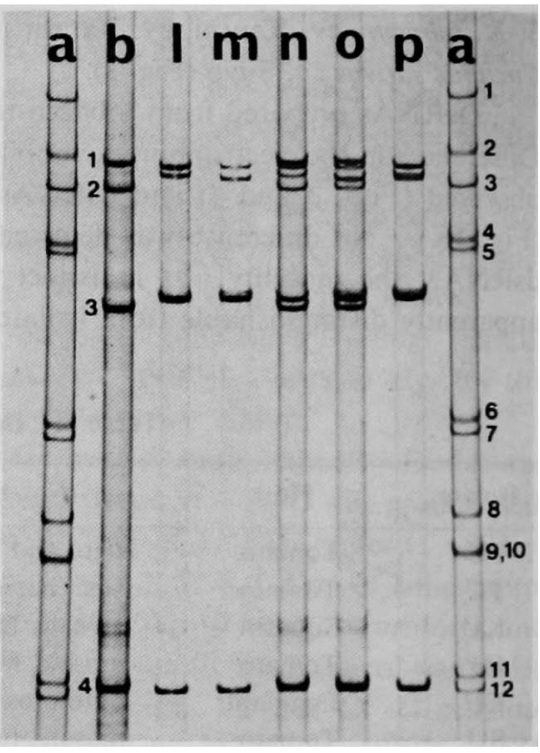

Fig. 4. Electrophoresis of dsRNAs associated with CMV-EU, PU or TU. RDV dsRNA (a), CMV-TU (b), PU (l), EU (m), TU+PU (n), TU+EU (o) and PU $+E U(p)$.

PU migrated more slowly than that of other isolates. Differences in dsRNA1 and dsRNA2 were detected, which were sufficient to distinguish the CMV isolates used in this study. The estimated molecular weights for dsRNAs were determined using rice dwarf virus dsRNA ${ }^{\text {s) }}$ as markers and were approximately double the value for CMV genomic ssRNAs, ${ }^{7,8)}$ (Table 2). Additional minor dsRNA were also observed (Figs. 3 and 4). It will be necessary to determine whether the minor dsRNAs are virus specific or related to the host ${ }^{5}$.

The observation that the mobility of dsRNA3 on electrophoresis was correlated with the serotype can be explained by the coat protein gene being on CMV genomic RNA3 ${ }^{8}$. The

8) Reddy, R.D.V., Kimura, I. and Black, L.M. (1974). Virology 60: 293-298. 9) Francki, R.I.B., Mossop, D.W. and Hatta, T. (1979). CMI/AAB Description of Plant Viruses. No. 213. 
detection of three kinds of dsRNA1 and four kinds of dsRNA2 from six isolates suggests that a large number of CMV variations are present in nature.

Our results indicate that five CMV isolates can be distinguished on the basis of electrophoretic migration of RF-dsRNAs on polyacrylamide gels. The lack of difference between CMVIU and SU in dsRNAs mobility, in symptoms of original host and serological characteristics suggests that both isolates are the same. Thus, dsRNA analysis has the potential to provide reliable evidence by which to categorize CMV isolates (strains) that have been confused until the present.

\section{和 文 摘 要}

王 蔚芹・夏秋知英・奥田諴一・寺中理明：袘製型二本鎖 RNAによる数種キュウリモザイクウイルス分 離株の比較

キュウリモザイクウイルス (CMV) の分離株間における核酸ゲノムの差異を知るために，CMV 感染葉か ら複製型二本鎖 RNA をCF-11 セルロースにより抽出し，銀染色を用いたポリフクリルアミドゲル電気泳 動による比較を行った。抽出に用いる植物の種類によって複製型二本鎖 RNA の奄気泳動パターンは变化 しなかった。用いた CMVの 6 分崔侏からは, 電気泳動度の異なる 3 種の RNA1，4 種の RNA2, 2 種の RNA3 が検出された。RNA3 の泳動度の差は血清型の差に一致していた。複製型二本鎖 RNAの電気泳動 によりCMVの系統判別が迅速容易に行兄ると考えられた。 